\title{
On the Effectiveness of Pelvic Floor Exercise for the Stress Urinary Incontinence Among Women
}

\author{
Pradnya Gavhale, Manjusha Mahakarkal and Vaishali Taksande \\ Department of Obstetrics and Gynaecological Nursing, Smt. Radhikabai Meghe Memorial \\ College of Nursing, Datta Meghe Institute of Medical Sciences, Sawangi, Wardha, Maharashtra India \\ Corresponding author email: pradnyagavhale1995@gmail.com
}

\begin{abstract}
The aim of the study to determine the efficacy of pelvic floor exercise for stress urinary incontinence. In this study interventional evaluatory approach \& time series research design were utilized. This research was carried out in a rural community area of Sawangi (Meghe) Wardha were 30 women who fulfill the criteria of sample selection that women selected as a sample according to non-probability purposive sampling technique. Significant difference were found before Et after pelvic floor exercise. The findings of the severity of stress urinary incontinence were $14(46.70 \%)$ of women had grade I in pre assessment whereas, 12 (40\%) of women had grade I in post assessment. A 16 (53.3\%) of women had grade II in pre assessment whereas, 6 (20\%) of women had grade II in post assessment. A 12 (40\%) of women had grade 0 in post assessment whereas, $0(0 \%)$ of women had grade 0 in pre assessment. Significant association was found between the history of mode of delivery of first attempt with stress urinary incontinence $(p=0.022)$ \& also, significant association was found between age $(p=0.031)$, marital status $(p=0.001)$ \& history of mode of delivery of second attempt $(p=0.016)$ with severity of stress urinary incontinence. Stress urinary incontinence is the main problem that may develop due to weak pelvic floor muscles \& only pelvic floor exercise is a primary treatment to improve pelvic muscle strength.
\end{abstract}

KEY WORDS: EFFECTIVENESS, PELVIC FLOOR EXERCISE, STRESS URINARY INCONTINENCE, SEVERITY OF STRESS URINARY INCONTINENCE, INGELMAN-SUNDBERG SCALE.

\section{INTRODUCTION}

Urinary incontinence is a medical disease in which the urinary bladder loses its control, which can range from a small amount of urine loss during sneezing, coughing, laughing, to a total loss of bladder control. It is a problem of involuntary leakage of urine \& classification according to symptoms and incidence of pathophysiological mechanisms. (Norton, Brubaker, 2006) Urinary stress incontinence is also known as a medical problem in which uncontrollable leakage of urine due to stress, effort, heavy exercise, sneezing, or coughing and urinary stress incontinence is a unique type of urinary incontinence. Urinary stress incontinence have a great effect on the standard of living of women $\mathrm{ft}$ can restrict professional

Biosc Biotech Res Comm P-ISSN: 0974-6455 E-ISSN: 2321-4007

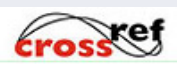

Identifiers and Pagination

Year: 2021 Vol: 14 No (9) Special Issue

Pages: 272-276

This is an open access article under Creative

Commons License Attribn 4.0 Intl (CC-BY). DOI: $h t t p: / / d x . d o i . o r g / 10.21786 / b b r c / 14.9 .51$ and individual activity and physical activity among women. (Montgomery, 2014.) Stress urinary incontinence is the commonest issue among females because of internal abdominal pressure like coughing, sneezing, laughing, running, exercises, and exertion. It is commonly found in females above the age of 15 years, stress urinary incontinence affecting certain age ranges and severity will be increased with age. This is a serious social health problem in young females which decreases the standard of living. (Sangsawang, 2013)

The study aims to determine the efficacy of pelvic floor exercise for the prevention and treating stress urinary incontinence. The objective was to assess the stress urinary incontinence among women before \&t after pelvic floor exercise, to assess the severity of stress urinary incontinence among women before \&t after pelvic floor exercise, to find out the association between stress urinary incontinence \&t severity with selected demographic variables. Urinary incontinence can damage the standard of living of an individual, $\&$ it will lead to a disturbing social relationship, depressive symptoms from embarrassment, and hospital stay because of urinary tract
Article Information

Received: $19^{\text {th }}$ Apr 2021

ccepted after revision: $25^{\text {th }}$ June 2021 
infection, skin breakdown. Stress urinary incontinence may affect sexual function. (Palmer, 1996) Urinary stress incontinence is a common issue, experiencing discomfort, guilt, or complete lack of self-esteem, including significant social and human consequences. It has an impact not only on the standard of living but also on the costs. (Lenderking et al., 1996)

\section{MATERIAL AND METHODS}

In this study time series research design $\&$ t an interventional evaluatory approach was used. The research was carried out in the rural community area of Sawangi Meghe, Wardha were 30 females who have fulfill the sample selection criteria that selected as a study sample according to the non-probability purposive sampling technique. Permission was taken from institutional ethical committee. The tools were a structured questionnaire on demographic variables and stress urinary incontinence, Ingelman-Sundberg scale for assessing the severity of stress urinary incontinence, Checklist of pelvic floor exercise used for data collection. The tool was supplied to 12 specialists from various fields of medical surgical nursing, obstetrical \& gynecological nursing. Expert suggestions \& recommendations were used to make changes in tools. Before collecting data, authorization was received from the relevant authorities in the chosen community area. Consent was received from the sample (Bokne et al., 2019).

Pelvic floor exercise was given by the researcher to the participant. Pilot research was carried out on 3 samples in a selected rural community area salod, Wardha. Data collection process on 1st day pre-assessment of stress urinary incontinence \& severity of stress urinary incontinence was done. On the same day, pelvic floor exercise was explained and demonstrated to those women who have grade I and II stress urinary incontinence. Instructed them to empty their bladder. They can sit, stand, and half lie with the leg slightly apart closed \& draw around the anal passage as through preventing a bowel action. Then they have to draw up around the vagina and urethra as if to stop the flow of urine in midstream hold for 10 seconds then relax and repeat 10 times. Instructed them to do pelvic floor exercise 3 times/ day for 2 weeks (morning, afternoon, night). Researcher monitor activities on 1st,4th,7th, 10th\&t 13th day after that post-assessment was done after 2 weeks to determine the efficacy of pelvic floor exercise by using tools.

\section{RESULTS AND DISCUSSION}

Grades of stress urinary incontinence are compared by using the Chi-square test. Significant difference was found in pre \& $\mathrm{t}$ post assessment. Significance of difference between the severity of stress urinary incontinence before \&t after pelvic floor exercise.

The above table shows the association of severity of stress urinary incontinence with age in years of women, marital status of women, and history of mode of delivery of women in the second attempt.
Section A Percentage-wise distribution of women according to demographic variables. $n=30$

\begin{tabular}{|c|c|c|}
\hline Demographic Variables & $\begin{array}{l}\text { Number of } \\
\text { Women (f) }\end{array}$ & $\begin{array}{l}\text { Percentage } \\
\quad(\%)\end{array}$ \\
\hline \multicolumn{3}{|l|}{ Age(yrs) } \\
\hline $31-40$ yrs. & 13 & 43.3 \\
\hline 41-50 yrs. & 4 & 13.3 \\
\hline $51-60$ yrs. & 8 & 26.7 \\
\hline$>60$ yrs. & 5 & 16.7 \\
\hline \multicolumn{3}{|l|}{ Marital Status } \\
\hline Married & 19 & 63.3 \\
\hline Unmarried & 0 & 0 \\
\hline Widow & 11 & 36.7 \\
\hline \multicolumn{3}{|l|}{ Number of children } \\
\hline No children & 0 & 0 \\
\hline One & 2 & 6.7 \\
\hline Two & 19 & 63.3 \\
\hline Three or more & 9 & 30 \\
\hline \multicolumn{3}{|l|}{ H/O birth canal injury } \\
\hline Yes & 1 & 3.3 \\
\hline No & 29 & 96.7 \\
\hline \multicolumn{3}{|l|}{$\begin{array}{l}\mathrm{H} / 0 \text { mode of delivery } \\
\text { 1stattempt }\end{array}$} \\
\hline Normal Delivery & 28 & 93.3 \\
\hline LSCS & 2 & 6.7 \\
\hline \multicolumn{3}{|l|}{ 2ndattempt } \\
\hline Normal Delivery & 24 & 85.7 \\
\hline LSCS & 4 & 14.2 \\
\hline \multicolumn{3}{|l|}{ 3rd attempt } \\
\hline Normal Delivery & 6 & 66.7 \\
\hline LSCS & 3 & 33.3 \\
\hline \multicolumn{3}{|l|}{4 th attempt } \\
\hline Normal Delivery & 2 & 66.7 \\
\hline LSCS & 1 & 33.3 \\
\hline \multicolumn{3}{|l|}{$\begin{array}{l}\mathrm{H} / 0 \text { previous abdominal } \\
\text { surgery }\end{array}$} \\
\hline Yes & 22 & 73.3 \\
\hline No & 8 & 26.7 \\
\hline
\end{tabular}

\section{DISCUSSION}

In this present study, the stress urinary incontinence is identified when unintentional leaking of urine with sudden pressure on the abdomen. According to analysis, it is found that $17(56.7 \%)$ of women had urine leak during running or picking up heavy objects in pre assessment whereas, $6(20 \%)$ of women had urine leak during running or picking up heavy objects in post assessment. 13(43.3\%) of women had urine leak when cough and sneeze in pre assessment whereas, 11(36.7\%) of women had urine leak when cough and sneeze post assessment. 13 (43.3\%) of women had urine never leak in post assessment whereas, $0(0 \%)$ of women had urine never leak in pre assessment. 9(30\%) of women had urine passed suddenly during the day in pre assessment whereas, 2(6.67\%) of women had urine passed suddenly 
during the day in post assessment. 21(70\%) of women had urine never passed suddenly during the day in pre assessment whereas, 28(93.33\%) of women had urine never passed suddenly during the day in post assessment.

Section B Assessment of stress urinary incontinence before $\mathrm{ft}$ after pelvic floor exercise. $\mathrm{n}=30$

\begin{tabular}{|c|c|c|c|}
\hline & $\begin{array}{c}\text { Pre } \\
\text { assessment }\end{array}$ & Post assessment & $\chi^{2}$-value \\
\hline \multicolumn{4}{|c|}{ When Does urine leak } \\
\hline Never & $0(0 \%)$ & $13(43.3 \%)$ & \multirow{4}{*}{$\begin{array}{l}18.43 \\
\mathrm{p}=\end{array}$} \\
\hline $\begin{array}{l}\text { Leak while running or picking up heavy } \\
\text { objects. }\end{array}$ & $17(56.7 \%)$ & $6(20 \%)$ & \\
\hline $\begin{array}{c}\text { Leak when you cough and } \\
\text { Sneeze }\end{array}$ & $13(43.3 \%)$ & $11(36.7 \%)$ & \\
\hline Leak all the time & $0(0 \%)$ & $0(0 \%)$ & \\
\hline \multicolumn{4}{|c|}{ Have you ever suddenly passed uine during the day } \\
\hline Yes & $9(30 \%)$ & $2(6.6 \%)$ & \multirow{2}{*}{$\begin{aligned} & 5.04 \\
\mathrm{p}= & 0.019, \mathrm{~S}\end{aligned}$} \\
\hline No & $21(70 \%)$ & $28(93.3 \%)$ & \\
\hline \multicolumn{4}{|c|}{ Do you pass uine by continuous dribbling } \\
\hline Yes & $7(23.3 \%)$ & $1(3.3 \%)$ & \multirow{2}{*}{$\begin{array}{c}5.19 \\
\mathrm{p}=0.022, \mathrm{~S}\end{array}$} \\
\hline No & $23(76.7 \%)$ & $29(96.6 \%)$ & \\
\hline \multicolumn{4}{|c|}{ How much does leaking urine interfere with yours everyday life } \\
\hline Not at all & $0(0 \%)$ & $10(33.3 \%)$ & \multirow{4}{*}{$\begin{aligned} & 27.46 \\
\mathrm{p}= & 0.0001, \mathrm{~S}\end{aligned}$} \\
\hline A little & $9(30 \%)$ & $17(56.7 \%)$ & \\
\hline Somewhat & $9(30 \%)$ & $3(10 \%)$ & \\
\hline A lot & $12(40 \%)$ & $0(0 \%)$ & \\
\hline \multicolumn{4}{|c|}{ If you need to go to the toilet to pass uine, how long can you hold on } \\
\hline $0-1$ minutes & $17(56.7 \%)$ & $0(0 \%)$ & \multirow{4}{*}{$\begin{aligned} & 20.05 \\
\mathrm{p}= & 0.0001, \mathrm{~S}\end{aligned}$} \\
\hline 1-5 minutes & $10(33.3 \%)$ & $11(36.7 \%)$ & \\
\hline $5-10$ minutes & $3(10 \%)$ & $9(30 \%)$ & \\
\hline$>10$ minutes & $0(0 \%)$ & $10(33.3 \%)$ & \\
\hline
\end{tabular}

Section C Significance of difference between the severity of stress urinary incontinence among women before $\mathrm{ct}$ after pelvic floor exercise. $\mathrm{n}=30$

\begin{tabular}{|l|c|c|c|}
\hline & $\begin{array}{c}\text { Pre } \\
\text { assessment }\end{array}$ & $\begin{array}{c}\text { Post } \\
\text { assessment }\end{array}$ & ₹2-value \\
\hline Grade 0 & $0(0 \%)$ & $12(40 \%)$ & 16.70 \\
\hline Grade I & $14(46.7 \%)$ & $12(40 \%)$ & $\mathrm{p}=0.0002, \mathrm{~S}$ \\
\hline Grade II & $16(53.3 \%)$ & $6(20 \%)$ & \\
\hline
\end{tabular}

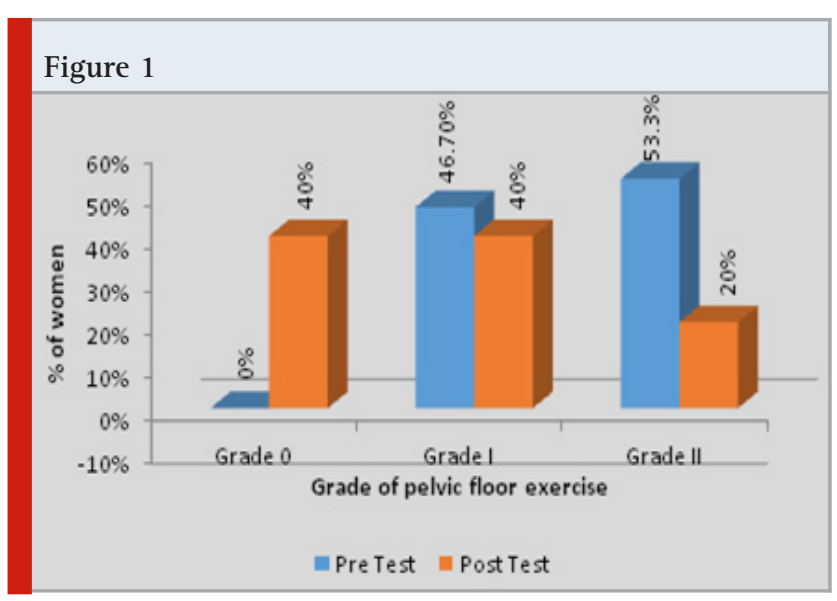

$7(23.30 \%)$ of women had urine lost by continuous dribbling in pre assessment whereas, $1(3.33 \%)$ of women had urine lost by continuous dribbling in post assessment. $23(76.7 \%)$ of women had urine never lost by continuous dribbling in pre assessment whereas, 29(96.67\%) of women had urine never lost by continuous dribbling in post assessment. 9(30\%) of women had urine leaking interfere a little in their everyday life in pre assessment whereas, $17(56.70 \%)$ of women had urine leaking interfere a little in their everyday life in post assessment. $9(30 \%)$ of women had urine leaking interfere somewhat in their everyday life in pre assessment whereas, 3(10\%) of women had urine leaking interfere somewhat in their everyday life in post assessment.

$12(40 \%)$ of women had urine leaking interfere a lot in their everyday life in pre assessment whereas, $0(0 \%)$ of women had urine leaking interfere a lot in their everyday life in post assessment. 10(33.30\%) of women had urine leaking not at all interfere in their everyday life in post assessment whereas, $0(0 \%)$ of women had urine leaking not at all interfere in their everyday life in pre assessment.10(33.3\%) of women are holding urine for 1-5 minutes in pre assessment whereas, $11(36.7 \%)$ of women are holding urine for 1-5 minutes in post assessment. $3(10 \%)$ of women are holding urine for 5-10 minutes in pre assessment whereas, 9(30\%) of women are holding urine for 5-10 minutes in post assessment. $0(0 \%)$ of women are holding urine for more than 10 minutes in pre assessment whereas, 10(33.3\%) of women are holding 
urine for more than 10 minutes in post assessment. in pre assessment whereas, $0(0 \%)$ of women are holding 17(56.7\%) of women are holding urine for 0-1 minutes urine for 0-1 minutes in post assessment.

Section D Association of stress urinary incontinence with selected demographic variables. $\mathrm{n}=30$

\begin{tabular}{|c|c|c|c|c|c|c|}
\hline $\begin{array}{c}\text { Demographic } \\
\text { variables }\end{array}$ & $\begin{array}{c}\text { No. of } \\
\text { women(f) }\end{array}$ & $\begin{array}{c}\text { Mean stress } \\
\text { urinary } \\
\text { incontinency }\end{array}$ & $\begin{array}{c}\text { F- } \\
\text { value/ } \\
\text { t- value }\end{array}$ & Df & $\begin{array}{l}\text { F-tab } \\
\text { value/ } \\
\text { t-tab } \\
\text { value }\end{array}$ & p-value \\
\hline \multicolumn{7}{|c|}{ Age (yrs) } \\
\hline $31-40$ yrs. & 13 & $10.30 \pm 0.75$ & \multirow{4}{*}{1.70} & \multirow{4}{*}{3,26} & \multirow{4}{*}{2.98} & \multirow{4}{*}{$\begin{array}{c}0.19 \\
N S, p>0.05\end{array}$} \\
\hline 41-50 yrs. & 4 & $10.75 \pm 1.50$ & & & & \\
\hline $51-60$ yrs. & 8 & $11.12 \pm 0.64$ & & & & \\
\hline$>60$ yrs. & 5 & $10.20 \pm 1.09$ & & & & \\
\hline \multicolumn{7}{|c|}{ Marital status } \\
\hline Married & 19 & $10.63 \pm 1.01$ & \multirow[t]{3}{*}{0.49} & \multirow[t]{3}{*}{28} & \multirow[t]{3}{*}{2.05} & \multirow{3}{*}{$\begin{array}{c}0.62 \\
N S, p>0.05\end{array}$} \\
\hline Unmarried & 0 & $\mathrm{O} \pm \mathrm{O}$ & & & & \\
\hline Widow & 11 & $10.45 \pm 0.82$ & & & & \\
\hline \multicolumn{7}{|c|}{ Number of children } \\
\hline No children & $\mathrm{O}$ & $\mathrm{O} \pm \mathrm{O}$ & \multirow{4}{*}{1.30} & \multirow{4}{*}{2,27} & \multirow{4}{*}{3.35} & \multirow{4}{*}{$\begin{aligned} 0.28 & \\
N S, p & >0.05\end{aligned}$} \\
\hline One & 2 & $11.50 \pm 2.12$ & & & & \\
\hline Two & 19 & $10.57 \pm 0.83$ & & & & \\
\hline Three or more & 9 & $10.33 \pm 0.86$ & & & & \\
\hline \multicolumn{7}{|c|}{$\mathrm{H} / \mathrm{O}$ birth canal injury } \\
\hline Yes & 1 & $11 \pm \mathrm{O}$ & \multirow[t]{2}{*}{0.46} & \multirow[t]{2}{*}{28} & \multirow[t]{2}{*}{2.05} & \multirow{2}{*}{$\begin{array}{c}0.64 \\
N S, p>0.05\end{array}$} \\
\hline No & 29 & $10.55 \pm 0.94$ & & & & \\
\hline \multicolumn{7}{|c|}{$\mathrm{H} / \mathrm{O}$ mode of delivery } \\
\hline \multicolumn{7}{|c|}{$1^{\text {st }}$ attempt } \\
\hline Normal Delivery & 28 & $10.46 \pm 0.83$ & \multirow{2}{*}{2.42} & \multirow{2}{*}{28} & \multirow{2}{*}{2.05} & \multirow{2}{*}{$\begin{array}{c}0.022 \\
\mathrm{~s}, \mathrm{p}<0.05\end{array}$} \\
\hline LSCS & 2 & $12 \pm 1.41$ & & & & \\
\hline \multicolumn{7}{|c|}{$2^{\text {nd }}$ attempt } \\
\hline Normal Delivery & 24 & $10.62 \pm 0.87$ & \multirow[t]{2}{*}{0.27} & \multirow[t]{2}{*}{28} & 2.05 & 0.78 \\
\hline $\mathrm{LSCS}$ & 4 & $10.50 \pm 0.57$ & & & & $N S, p>0.05$ \\
\hline & & $3^{\text {rd }}$ atter & & & & \\
\hline Normal Delivery & 6 & $10.33 \pm 0.81$ & 1.36 & 28 & 2.05 & 0.21 \\
\hline $\mathrm{LSCS}$ & 3 & $11 \pm 0$ & & & & NS, $p>0.05$ \\
\hline & & $4^{\text {th }}$ atter & & & & \\
\hline Normal Delivery & 2 & $11 \pm 0$ & - & - & - & - \\
\hline LSCS & 1 & $11 \pm 0$ & & & & \\
\hline & & previous abdo & nal surg & & & \\
\hline Yes & 22 & $10.50 \pm 0.96$ & 0.64 & 28 & 2.05 & 0.52 \\
\hline No & 8 & $10.75 \pm 0.88$ & & & & $\mathrm{NS}, \mathrm{p}>0.05$ \\
\hline
\end{tabular}

Section E Association of severity of stress urinary incontinence with selected demographic variables. $n=30$

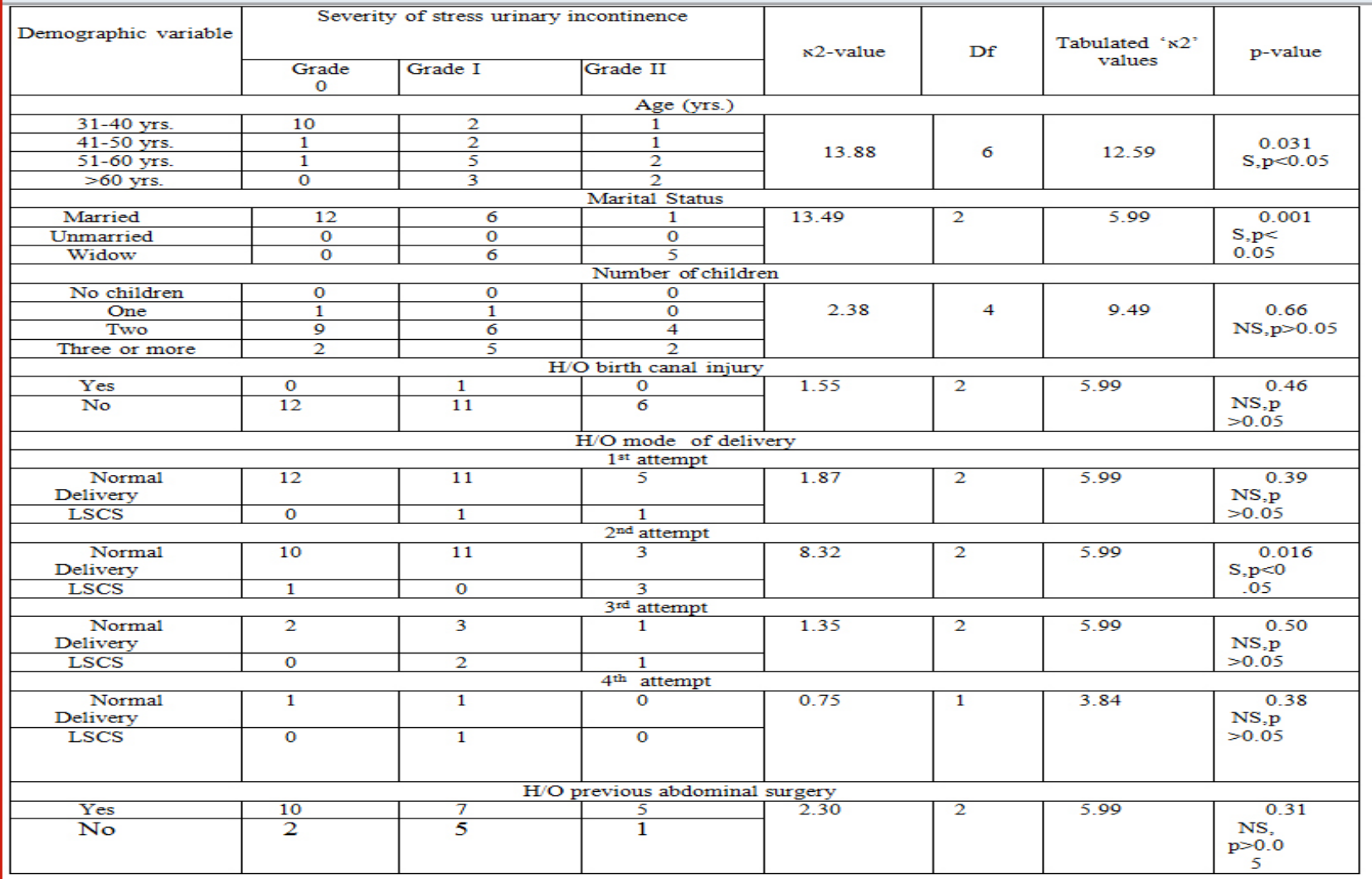


A study was supported by a parallel group randomized controlled trial which was conducted in twenty three community \& secondary care centers providing continence care in Scotland \& England where 600 women were selected as samples. Mean ICIQ-UI SF scores at 24 months were 8.2 in the biofeedback pelvic floor muscles training group \& 8.5 in the pelvic floor muscle training group.( Neumann, Grimmer, Deenadayalan, 2006) In this present study, 14 (46.70 \%) of women had grade I severity of stress urinary incontinence in pre assessment whereas, 12 (40\%) of women had grade I severity of stress urinary incontinence in post assessment. 16 (53.3\%) of women had grade II severity of stress urinary incontinence in pre assessment whereas, 6 (20\%) of women had grade II severity of stress urinary incontinence in post assessment. 12 (40\%) of women had a grade 0 severity of stress urinary incontinence in post assessment whereas, $0(0 \%)$ of women had a grade 0 severity of stress urinary incontinence in pre assessment.

The research were supported by a prospective longitudinal observational study which was carried out in Tertiary referral urogynecology center, France. This shows, 17 $(20 \%)$ of women stress urinary incontinence grade 1 was cured whereas, 4 (20\%) of women were not cured. $20(24 \%)$ of women stress urinary incontinence grade 2 cured whereas, 4 (20\%) of women was not cured. 36 $(42 \%)$ of women stress urinary incontinence grade 3 cured whereas, 6 (30\%) women were not cured.( Bokne, Sjöström, Samuelsson, 2019) In this present study, the history of mode of delivery of women in the first attempt was significantly associated with their stress urinary incontinence and severity of stress urinary incontinence is significantly associated with age, marital status, \& history of mode of delivery of women in the second attempt. A supportive cross-sectional study were conducted in Iran. In this study, 90 married women were selected randomly. This study revealed that stress urinary incontinence is significantly associated with vaginal delivery $(\mathrm{p}=0.035, \mathrm{p}<0.05)$. (Langa, Fultz, Saint et al 2002)

\section{CONCLUSION}

Stress urinary incontinence is the main problem which may develop due to weak pelvic floor muscles. This research reveals that the assessment of stress urinary incontinence \&t severity among females is significantly associated with before \& after pelvic floor exercise. This research has proven that pelvic floor exercise is beneficial for stress urinary incontinence. Association of severity of stress urinary incontinence found with age in years of women, marital status of women, and history of mode of delivery of women in the second attempt \& association of stress urinary incontinence found with the history of mode of delivery of women in the first attempt.

\section{REFERENCES}

Bokne, K., Sjöström, M. and Samuelsson, E., (2019). Self-management of stress urinary incontinence: effectiveness of two treatment programmes focused on pelvic floor muscle training, one booklet and one Internet-based. Scandinavian journal of primary health care, 37(3), pp.380-387.

Langa, K.M., Fultz, N.H., Saint, S., Kabeto, M.U. and Herzog, A.R., (2002). Informal caregiving time and costs for urinary incontinence in older individuals in the United States. Journal of the American Geriatrics Society, 50(4), pp.733-737.

Lenderking, W.R., Nackley, J.F., Anderson, R.B. and Testa, M.A., (1996). A review of the quality-of-life aspects of urinary urge incontinence. Pharmacoeconomics, 9(1), pp.11-23.

Montgomery, E., (2014). Regaining Bladder Control: For Incontinence on Exertion Or Following Pelvic Surgery. Elsevier.

Neumann, P.B., Grimmer, K.A. and Deenadayalan, Y., (2006). Pelvic floor muscle training and adjunctive therapies for the treatment of stress urinary incontinence in women: a systematic review. BMC Women's Health, 6(1), pp.1-28.

Norton, P. and Brubaker, L., (2006). Urinary incontinence in women. The Lancet, 367(9504), pp.57-67.

Palmer, M.H., 1996. Urinary continence: Assessment and promotion. Jones \& Bartlett Learning.

Sangsawang, B. and Sangsawang, N., (2013). Stress urinary incontinence in pregnant women: a review of prevalence, pathophysiology, and treatment. International urogynecology journal, 24(6), pp.901912. 